Editorial

\title{
Ver os que os outros não podem ver
}

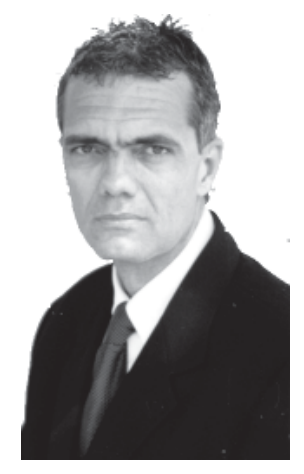

Marco A ntonio G uimarães da Silva,M ed.D r.Sci. marco@ atlanticaedu.com.br

Com uma programação que incluía entre outros temas a discussão sobre "A importância dos Periódicos de Fisioterapia no Desenvolvimento da Pós-graduação stricto sensu na área de Fisioterapia", a Universidade Federal de São Carlos organizou, no mês de maio deste ano, I Fórum Nacional de Pós-graduação stricto sensu em Fisioterapia. Os editores das principais revistas da área de fisioterapia, especialmente as indexadas, foram convidados para participarem do evento. A Revista Fisioterapia Brasil, por mim representada, adotou uma linha de discussão distinta sobre o tema proposto que acreditamos merece melhor explicitação. A pesar de algumas digressões, recorro ao pensamento do Foucault para amparar os argumentos sobre a questão que trarei a seguir.

No primeiro capitulo do livro As palavras e as coisas (Foucault,1966), o filósofo faz um estudo do quadro L as M eninas, de Velásquez, no qual o pintor apresenta os personagens desde várias perspectivas e como protagonistas de um jogo de esconder e revelar, que oferece vários ângulos: 0 quadro pode ser visto a partir do espectador, a partir do rei ou a partir do pintor, mas com a particularidade de que cada personagem vê o quadro desde uma perspectiva distinta e, ao mesmo tempo, vê o que o outro não pode ver, sem ser visto pelos outros. 0 que destaca Foucault e o que nos interessa destacar no presente editorial são os múltiplos planos existentes nesse quadro: 0 nível de percepção queVelásquez simboliza com a luz que penetra pelajanela retratada no quadro e o nível de linguagem, ambos distintos e seguindo suas próprias leis. É essa situação que trago para refletir sobre o referido encontro que se propunha discutir a importância dos periódicos de Fisioterapia.

Todos os editores presentes ao evento (exceção para Fisioterapia Brasil) optaram por focalizar as suas apresentações nas normas e procedimentos para a seleção de artigos. Seguindo o olhar plural foucaultiano, sugerido pelo quadro de Velásquez, vislumbrei uma outra perspectiva voltada para a interpretação textual do significado no assunto título do evento e adotei um discurso que não coincidiu com 0 apresentado pelos outros colegas editores. Procurei discutir a questão sobre uma ótica que se opõe diametralmente à exposta no título "Importância dos Periódicos de Fisioterapia no D esenvolvimento da Pós-graduação stricto sensu na área de Fisioterapia". Se o nosso olhar e nossa percepção fossem menos enrijecidos, poderíamos ampliar nosso debate, discutindo exatamente o oposto do sugerido pela maioria dos presentes. Passaríamos a discutir alguma coisa como: A importância da Pósgraduação stricto sensu na área de Fisioterapia para 0 D esenvolvimento dos periódioos.

Já se sabe que a importância dos periódicos da área de fisioterapia, ou de qualquer área, está representada pela oportunidade de publicação que esses mesmos periódicos oferecem àqueles que terminaram suas pesquisas. O bviamente também já conhecemos o papel ímpar desses veículos de divulgação para a produção de novos conhecimentos científicos. Mas sobreviveríamos, como revistas, sem a produção cientifica dos docentes e alunos dos programas de pós-graduação? Talvez sim, mas com uma periodicidade muito aquém da desejada e que talvez não atendesse às regras dos indexadores. Além desta questão, existe ainda a qualidade da pesquisa, que, boa ou ruim, uma vez concluída acaba gerando um ou mais artigos. Pesquisas com delineamentos equivocados e com resultados que não têm fôlego para resistirem a uma análise baseada na palavra de moda (evidências) são muito freqüentes. Mais umavez, a Pós-graduação stricto sensu pode ser de vital importância no desenvolvimento de periódicos ena manutenção de seus padrões de qualidade, já que o entorno acadêmico é um foro privilegiado para providências que equacionem os erros cometidos nas investigações cientificas. Entretanto, para chegarmos a novas conclusões, é preciso que saibamos, como nos ensina Foucault através do quadro de Velásquez, desdobrar o nosso olhar e fazer com que ele busque novas perspectivas.

A nossa simples existência, como revista indexada, oferece a perspectiva alternativa que simboliza a importância que temos para o desenvolvimento da pós-graduação na área da fisioterapia ou de quaisquer outras áreas. Existir e nada mais, eis a nossa contribuição. 